\title{
Network Based Online Learning Program Vocational School in Jakarta State University
}

\author{
Suyitno Muslim, Jhoni Lagun Siang, Aniesa Puspa Arum
}

\begin{abstract}
The purpose of this study is the development of online learning based learning in the course of research methodology to improve learning competencies in the subject of research methodology in the Electrical Engineering Vocational Education Study Program FT-UNJ. The development of learning that will be developed is online learning based learning which combines face-to-face learning with online learning which is arranged in such a way using the Edmodo platform. The strategy of delivering this learning is done with $70 \%$ face-to-face and 30\% online learning, for learning purposes that are understanding and concept development is very likely to be done online but for learning purposes in the form of skills that require learning processes in the form of practical activities face to face form. The target in this study was students who temporarily took research methodology courses in Vocational Education Program in Electrical Engineering FT-UNJ. Since this research is in the form of developing an online learning system, the research method used is research and development $(R \& D)$. The approach used in this study uses a systems approach which refers to the concept of research and development by Dick and Carey. All steps will be carried out systematically where when doing the next step, the previous steps must be completed first. The results showed that the development of online-based learning in research methodology courses used Dick and Carey's learning development model by utilizing the Edmodo platform, student interest and interest increased but student learning outcomes were not maximal. This is because the online learning based learning model is still relatively new, so it requires a short time process.
\end{abstract}

Keywords: Online Learning, research and development, Edmodo

\section{INTRODUCTION}

The development of information and communication technology is advancing so fast, reaching all sectors of life. Even its development is estimated to be more rapid than originally estimated. We still remember, three to four years ago information and communication technology such as computers and web-based cellular telephones were still expensive and only owned by certain people, but today the

Revised Manuscript Received on September 22, 2019

Suyitno Muslim, Profesor at Universitas Negeri Jakarta, Rawamangun Muka Street, Rawamangun, Pulogadung, East Jakarta, 13220, Indonesia. Yitno_muslim@yahoo.com

Jhoni Lagun Siang, Post Graduated Department of Educational Technology Universitas Negeri Jakarta, Rawamangun Muka Street, Rawamangun, Pulogadung, East Jakarta, 13220, Indonesia. jhonilagunsiang@yahoo.co.id

Aniesa Puspa Arum, Post Graduated Department of Educational Technology Universitas Negeri Jakarta, Rawamangun Muka Street, Rawamangun, Pulogadung, East Jakarta, 13220, Indonesia. aniesa.puspa@gmail.com

technology is no longer owned by certain people but belongs to all nations, belonging to everyone from the lowest to the top. In fact, many people cannot escape the technology in their daily lives, from morning to evening and until morning again. Information and communication technology quickly and revolutionary has changed the mindset and human civilization (1)

When looking for a moment, how the learning process takes place in each individual, it is found that the learning process occurs because of the interaction between people who learn and messages that are packaged in a variety of specific media. It can be in the form of a medium that is only used (by utilization), it can also be deliberately designed (by design) to achieve certain goals. Therefore, learning can happen anytime, anywhere, with anything.

The electrical engineering vocational education study program at UNJ is one of the study programs that has not fully implemented information and communication technology in learning. The availability of adequate facilities and infrastructure and internet facilities is not really used by lecturers and students to improve the quality of learning. This is because learning that is used still uses a face-to-face learning system. Based on the results of the initial analysis, several problems were found to be investigated. One of them is the learning system used. The learning system that is used in general is still using face-to-face learning, the lecturer as the main learning source in learning. In the classroom, students are only passive listeners, listening and recording what the lecturers say. This makes the atmosphere of learning in the classroom feels stiff, very boring and there is no active communication between lecturers and students. Students are faced with the same learning system every day, without any other learning systems that can pump students' motivation to take lessons with enthusiasm. Of course, this is a serious problem because it affects the achievement of learning competencies.

In response to the above problems, an-based learning process will be applied online learning in learning especially in the subject of research methodology. Why should be based online learning? Online learning is one of the learning models that can be offered to improve the quality of learning. This learning model is a combination of face-to-face learning systems and online learning. 


\section{LITERATURE REVIEW}

\section{A. Definition of Learning Models}

Models are a plan or a pattern that is used as a guide in planning classroom learning or tutorial learning. According to Arends as quoted by Trianto, the learning model refers to the learning approach that will be used, including the teaching objectives, the stages in learning activities, the learning environment and classroom management. This is in accordance with the opinion of Joyce quoted by Trianto that "Each model guides us as a design instruction to help students achieve various objectives" (2).

According to Joyce and Weil cited by Trianto stated that:

"Models of teaching are really models of learning. As we help students acquire information, ideas, skills, values, ways of thinking and expressing themselves, we also teach them how to learn (2).

The learning model refers to the learning approach that will be used, including the teaching objectives, the stages of learning activities, the learning environment, and classroom management.

1) Steps for Developing Learning Models

According to Suprijono in the outline of developing a learning model through the following steps:

- $\quad$ Set goals to be achieved. The goals set are general details, both individual goals and group goals.

- $\quad$ Set standards of success. The standard of success includes quality standards.

- $\quad$ Establish an evaluation system. Evaluation systems include process evaluation and outcome evaluation.

- Analyze situations and conditions related to the objectives to be achieved. Analysis is concentrated on the disclosure of supporting and inhibiting factors for achieving learning objectives.

- $\quad$ Establish learning activities that will be carried out to achieve learning goals. The defined learning activities have considered the supporting and inhibiting factors for achieving learning objectives through an analysis of the situations and conditions related to the learning objectives to be achieved.

- Setting the hierarchical goals of learning activities to achieve learning goals.

- $\quad$ Establish alternative learning activities to anticipate the possibility of ineffective and inefficient learning activities that have been determined.

- $\quad$ Allocate the time needed to complete each learning activity. (2)

\section{B. Learning Online}

According to Dabbagh and Bannan-Ritland cited by Prawiradilaga (2012) states that online learning is:

"an open and distributed learning environment that uses pedagogical approaches, enabled by internet and Web-based technologies, to facilitate learning and knowledge building through meaningful action and interaction" (3).

Their concept states that online learning uses global network facilities to deliver teaching material and use it to create interactions between teachers and students or between students. In doing so, they mentioned the application of certain learning strategies such as collaborative learning, role playing, exploration, or assignment. The learning technology or learning technologies are interpreted as material presentation patterns such as synchronous, or asynchronous, the application of the concept of hypermedia, multimedia, the use of LMS / LCMS. In addition, the pedagogical model is related to the form of online learning itself, namely flexible learning, distributed learning, and so on. Model selection is often associated with the availability of existing infrastructure. The three core components, working as a system, support each other in creating learning models through cyberspace.

Fig 1 Core Components of Online Learning (3)

In this connection, Dabbagh identifies six characteristics of online learning, namely:

- Globalization and learning as a social process are inherent and enabled through telecommunications technology.

- $\quad$ The concept of a learning group is fundamental to achieving and sustaining learning.

- The concept of distance is relatively unimportant or not limited to the physical separation of the learner and the instructor.

- Teaching and learning events are distributed across time and place, accruing synchronously and / or asynchronously through different media.

- Learner are engaged in multiple forms: learner-learner, learner-group, learner-content, and learner-instructor.

- Internet and / or web-based technologies and to facilitate learning and knowledge building through meaningful action and interaction (4).

learning Online, otherwise known as electronic learning, or e-learning is learning delivered by using electronics such as computers. Generally to access material online learning through networks, websites, internet, intranet, cd and DVD (5). Dabbagh and Ritland (2005), define online learning as an open learning environment that uses pedagogical, internet and-based technologies web as an effort to facilitate learning and knowledge building through meaningful interactions and activities (4). The use of networks, web and internet in defining online learning is also concluded by Richey, Klein, and Tracey (2011), stating that: Online learning is instruction delivered using the Web, the Internet and other distance technologies (6). Online learning is learning delivered using the web, internet and distance education technology. 
Joliffee, Ritter and Steven (2001), use another term for online learning, namely web based learning because the web is a very rich learning environment for building and delivering material online. Features such as email, discussion forums, video conferences, lectures online can be done with the web as well as some components of the facilitator of learning can be done with web-based learning (7).

Harasim (2012), defines online learning with 3 (three) models, namely

- $\quad$ Online Collaborative Learning (OCL): Application of education by emphasizing collaborative discourse and building infrastructure mediated by the internet.

- Online Distance Education (ODE): a correspondence model for delivering learning, independent learning and private communication to tutors.

- Online courseware: independent learning without interaction with instructors or colleagues (8).

- With the development of information technology, online learning utilizes the development of internet networks with various advantages as a medium for delivering learning messages. This was stated by Haughey and Anderson (1998), that:

Online learning as the use of the Internet to access learning materials; to interact with the content, instructors, and other learners; during the learning process, in order to acquire knowledge, to construct personal meaning, and to grow from the learning experience (9).

Anderson stated that online learning is an environment designed by utilizing internet technology to access learning materials, to facilitate learning by creating interactions between students and instructors or between participants of the students, so that knowledge that is meaningful and brings new experiences to students is obtained. Thus, it can be said that the core of online learning is creating learning experiences by utilizing internet technology in an appropriate manner to create an interaction space

\section{The Meaning of Online Learning}

Based on previous definitions and descriptions, both those that are concurrent and different, the implicit meanings of online learning are pleased with the learning process and learning opportunities. The process of learning as part of the life of an advanced society provides an opportunity for each individual to develop. For this reason, physical boundaries such as buildings, learning locations, teacher attendance are not absolutely necessary for the learning process. The progress and establishment of digital technology applied in the world of education facilitates and accelerates learning access including the delivery of teaching materials to be faster, easier, and more affordable.

Interaction in an environment online is less intimidating between individuals and also has less time pressure on students than interacting in a face-to-face habit. Discussions Online can also encourage more quiet students to participate for the most part. However, the benefits of interaction online may not be realized if closed connections between students are absent. Hay Thornthwaite and his colleagues found that students who failed to make an connection online with other students in their group reported feeling isolated and more stressed.

The characteristics of learning online are:

- Learning material is made from text, graphics, multimedia such as video, audio and animation.

- Synchronous and asynchronous communication applications such as conference videos, chat rooms, or discussion forums.

- Use of a web browser.

- Storage, maintenance and administration of material is on the server web.

Use of the TCP / IP protocol to facilitate communication between learners and learning material or resources (7).

Table 2.5.Advantages and Weaknesses Online Learning

\section{Sources of Excellence in $\quad$ Weaknesses of}

1. Variations of diverse media

2. The information
Sharon E.

Smaldino,

Deborah L.

Lowther and James

D. Russell

Sources of provided is up to date information

3.The navigation is easy to operate

4. Facilitating the exchange of ideas. not necessarily suitable

2. Copyright. Because the material is easily obtained, allowing individuals to use material improperly.

5. Comfortable communication. For example, email can be used as a communication medium that can be accessed anytime and anywhere

6. Low cost. The cost of hardware, software and internet services decreases over time
3. It is difficult to find information that can support effective learning.

4. Very dependent on

5. Very dependent on internet access, including speed.

6. Lack of control over quality.
1. Learning material is technical support.

Excellence

Weaknesses of 


\begin{tabular}{|c|c|c|}
\hline $\begin{array}{c}\text { Allan } \\
\text { Jolliffe, } \\
\text { Jonathan } \\
\text { Ritter and } \\
\text { David } \\
\text { Steven's }\end{array}$ & $\begin{array}{l}\text { 7. Can be used to } \\
\text { deliver learning } \\
\text { anytime and } \\
\text { anywhere. } \\
\text { 8. Can be used with } \\
\text { various CD } \\
\text { ROM-based } \\
\text { learning with } \\
\text { the addition of } \\
\text { communication } \\
\text { elements. } \\
\text { 9. Can increase } \\
\text { interaction } \\
\text { between learners } \\
\text { and facilitators. } \\
\text { 10. Learning material } \\
\text { is easy to update. } \\
\text { 11. Learners can } \\
\text { create a } \\
\text { web-based } \\
\text { informal and } \\
\text { formal } \\
\text { community. } \\
\text { 12. Allows giving } \\
\text { learning } \\
\text { assignments. } \\
\text { animation into } \\
\text { learning } \\
\text { material. } \\
\text { 13. Can use resources } \\
\text { that are already } \\
\text { available on the } \\
\text { internet. } \\
\text { such as text, } \\
\text { 14. Can present } \\
\text { learning content } \\
\text { in real time } \\
\text { using video } \\
\text { conferencing, } \\
\text { video streaming. } \\
\text { Can be used with } \\
\text { multiple media } \\
\text { 15ics, audio, }\end{array}$ & $\begin{array}{l}\text { 7. Technical } \\
\text { limitations cause } \\
\text { the learning } \\
\text { environment to } \\
\text { adjust to the } \\
\text { technological } \\
\text { devices currently in } \\
\text { use. } \\
\text { 8. The learning } \\
\text { environment is } \\
\text { online relatively } \\
\text { more expensive. } \\
\text { 9. Material design } \\
\text { must have } \\
\text { knowledge of } \\
\text { computer-based } \\
\text { learning to design } \\
\text { an effective } \\
\text { learning } \\
\text { environment. } \\
\text { 10. Limited bandwidth } \\
\text { causes problems } \\
\text { when downloading } \\
\text { downloadable } \\
\text { material. } \\
\text { trained in how to } \\
\text { resources. } \\
\text { learning. } \\
\text { 11. Some material } \\
\text { requires knowledge } \\
\text { of the computer } \\
\text { from the learner } \\
\text { and the latest } \\
\text { browser. } \\
\text { tomputer-based } \\
\text { 12. Training must be } \\
\text { provided for } \\
\text { facilitators and } \\
\text { learners. The } \\
\text { facilitator is } \\
\text { expected to be able } \\
\text { tevelop, } \\
\text { forners must be }\end{array}$ \\
\hline
\end{tabular}

\section{1) Learning Model Online}

There are 2 (two)learning models online learning:

(1)Fully online course: the learning environment is done online, where the learning process and interactions take place virtually (4).

According to Roblyer (2016) fully online course is divided into 3 models, namely:

- Model online interactive(Non-Noninteractive Online Model): Students read and study material in the form of text, links, videos, or independent exercises then do antest online to measure the achievement of the learning.

- Model Online Asynchronous Interactive(The Interactive, Asynchronous Online Model): This model is more commonly used in learning online by utilizing a Learning Management System (LMS).

- model online Interactive Synchronous (The Interactive online models with synchronous Event):learning model online in Realtime. In this model the interaction between students and instructors is done with the help of camera and communication devices online such as Adobe Connect, go to Meeting. This learning combines online meetings with learning activities online (10).

(2) Blended Learning: a learning method that combines face-to-face learning methods with online learning (4).

There are 3models blended learning commonly used in learning and training, namely:

- Traditional classes with online activities learning activities are online used to enrich learning activities in traditional classes.

- Classes Online with face-to-face activities: learning activities are conducted online, but there are face-to-face activities carried out. For example students are asked to attend to the exam, there is a visit to learning resources to study learning, hold face-to-face classes between learning facilitators and students to discuss several topics in an effort to involve students in learning

- Flipped classroom model: a learning model where the teacher assigns tasks to students to actively learn in advance the material to be delivered through digital media in the form of videos or e-books along with some task instructions / problem training, as discussion material during classroom activities advance) (10).

Learning online was developed with reference to the theory of teaching and learning. The use of digital technology and the internet for learning processes has an impact on one's learning patterns. The concept of independent and constructive learning is important in designing learning online.

\section{Methodology/Materials}

The purpose of this study is the development of based online learning in research methodology courses to improve learning competencies.

\section{A. Characteristics ofLearning Learning Development The Online}

Development of learning that will be developed is based online learning which combines face-to-face learning with online learning which is arranged in such a way using the platform Edmodo. The strategy of delivering this learning is done with $70 \%$ face-to-face and $30 \%$ online learning, for learning purposes that are understanding, and concept development is very likely to be done online but for learning purposes in the form of skills that require learning processes in the form of practical activities face to face form. Learning material Blended allows students to do learning online, and the learning process requires students to learn actively independently by using media Edmodo that has been designed in the form of 
learning videos, as well as teaching materials in the form of PowerPoints as well as .pdf, .doc, etc.

\section{B. Approaches and Methods}

Referring to the purpose of the study that seeks to improve the learning competencies, the research method used is research and development(research and development).

The approach used in this study uses a systems approach which refers to the concept of research and development developed by Dick and Carey (2009) (11). All steps will be carried out systematically where when doing the next step, the previous steps must be completed first.

\section{RESULTS AND FINDINGS}

\section{A. Results of Learning Development Online}

\section{1) Identify Instructional goals (Identifying} Instructional Objectives)

Research on the development of-based learning network(online) in the Electrical Engineering Vocational Education Study Program at the Faculty of Engineering, UNJ. The first step is to find out the obstacles and needs experienced by students in learning, researchers conducted interviews with students. Some of the indicators asked to students include the situation and conditions of teaching and learning activities, students' knowledge of learning online and how much students want if a model of learning is developed online. From the results of these interviews, there are several things that were revealed, including:

- Learning activities carried out in class are very boring, because there is no active communication between lecturers and students.

- In the classroom students are only active listeners, listening to and recording what the lecturers say.

- $\quad$ Students are faced with the same learning system every day without any other learning system that can pump the motivation of students to take lessons with enthusiasm.

- Students really hope that teachers can take advantage of technological developments as a medium for learning.

- Students really hope that the model online can be applied.

2) Conducting Instructional Analysis

At the instructional analysis stage the researcher analyzes the curriculum used. From the results of curriculum analysts, several competencies must be achieved, namely: 1) Understanding research methodology, 2) Understanding the flow of research 3) understanding the types of research. In developing-based learning online in research methodology courses.

\section{3) Identifying Students 'Behavior and Early \\ Characteristics}

In addition to identifying students' initial behavior researchers also identify student characteristics. The first step is to determine the behavior and initial characteristics of students, researchers conducted interviews.

From the results of these interviews, there were several things that were revealed, including:
- The educational background of students generally comes from Jakarta High School.

- The learning motivation of students is not good, this is characterized by the lack of active students in receiving the material taught by the lecturer and the low learning outcomes.

- $\quad$ The learning resources used by lecturers in research methodology subjects are still very few.

- Independent learning habits from students are still very weak

- Access to communication channels and communication technology media is very good, this is indicated by students using mobile phones that already have android features and the availability of free wifi to support students in accessing information quickly via the internet.

- In general, the distance to the center of student learning is not far from home.

4) Write Performance Objectives Specific

Instructional goals are the only basis for compiling test items and tools for testing the validity of test contents. In determining the content of the lesson to be taught. In other words, the content of the lessons to be taught is adjusted to what will be achieved.

\section{5) Develop Assessment Instruments (Developing}

Learning Outcomes Assessment Tools) Learning

outcomes assessment tools that should be prepared are tools that measure the level of achievement of students in the competencies contained in instructional objectives. The assessment tool may not need to measure learners' mastery of all teacher descriptions in the instructional process, because what the teacher gives during the process is not necessarily entirely relevant to the instructional objectives. Instructional content is not a criterion for measuring the success of the instructional implementation process but is part of the process and must be tested for its relevance to instructional objectives.

\section{6) Develop Instructional Strategy (Arranging Instructional Strategies)}

The instructional activity phase, namely the initial stages of instructional activities, presentation of contents, student participation, assessment, and follow-up activities. The five stages are one part of the instructional strategy. Each stage consists of steps of activity. The initial stage of instructional activities consists of activities to attract attention, explain instructional goals, explain and remind prerequisite skills. The content presentation phase consists of explaining the contents and providing study guidance. The participatory phase of learners consists of practice and feedback. The assessment phase consists of initial skill tests, initial tests and final tests. The final stage is a follow-up activity which consists of providing assistance to recall the material that has been studied and consideration of possible application of instructional content and competencies that have been achieved in life and relevant fields.

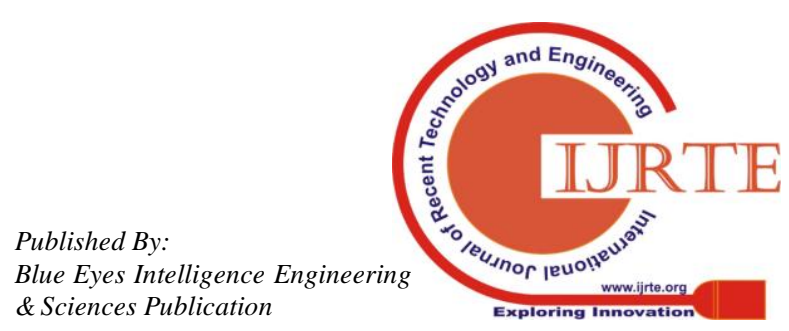




\section{7) Develop and Select Instructional Materials}

(Developing Instructional Materials)

At this stage learning materials that are relevant to the existing curriculum are selected and adapted to existing basic competencies. The basic material and competencies that exist are then linked to competency maps in the course of research methodology. The material presented in each meeting is in the form of video, animation, PowerPoint and pdf.

Research and development of-based learning online in research methodology courses using the Edmodo platform displays material in the form of .pdf, PowerPoint, PowToon and video files with easy language and attractive appearance so that it motivates students to study material independently.

The following is a display of-based research methodology material online that utilizes the Edmodo platform as a medium in applying online-based learning processes. The steps for using the Edmodo platform for students:

Students visit www.edmodo.com then select the button I'm a Student

Fig 2 Display Home Edmodo

Fill in the registration form with the Group Code, student name (username) and password (password) that are unique. In this case students are advised to use a first name added according to the unique behind it. For lines first name and last name, students must fill in their real names. In registering as a student, the e-mail address is not required to be filled out so that it can be filled in or emptied. However, it would be better if the email is still filled with student e-mail so that any notifications from Edmodo will also be sent to the student's e-mail. Class code that the lecturer has given to students to join the class Metlitis $476 z b 4$
To start the class online learning using the Edmodo platform, the lecturer has made a group with the name Metlit with the aim that all the material to be delivered will be sent via the Edmodo platform in the form of videos, YouTube links, PowToon applications or in the form of pdf and PowerPoint files. Following is the appearance of the Metlit class:

Fig 4 Class Menu Display Metlit

\section{8) Design and Conduct Formative Evaluation of Instruction (Arranging Designs and Implementing Formative Evaluations)}

Expert Judgment Feasibility Test The

first trial was conducted by media experts, material experts and learning design experts.

\section{a) First Stage Assessment}

\section{Media Experts}

Following is the elaboration of the results of the trial recapitulation of products based learning development online on in the Research Methodology course assessed by media experts

Table 2 Recapitulation of Media Experts

\begin{tabular}{cc}
\hline Component & Average Assessment \\
\hline 1. Access $\quad$ Accessibility & 3.50 \\
2. Access Complexity Level & 3 \\
3. Access Speed & 3 \\
4. $\quad$ Program Flexibility & 4 \\
Display / Interface & 4 \\
1. Choice of font size & 1.43
\end{tabular}

Fig 3 Display of Student Registration 


\section{Choice of type}

3. Use of color combinations for text

4. Use of animation

5. Graphic design

6. Navigation

$$
\text { 7. Layout }
$$

Learning Components

1.Presentation of learning / competency objectives

2. Submission of Apperception

3. Presentation of Motivation

4. Material Presentation

5. Submission of Tasks and Exercises

6. Submission of Evaluation

7. Giving Strengthening

8. Reference / Reference Presentation

Accuracy / suitability of choice of learning components for model blended learning

1. Learning Objectives / Competencies

$\begin{array}{lc}\text { 2. Material } & 2 \\ \text { 3. Method } & 2 \\ \text { 4. Evaluation } & 2 \\ & 3 \\ \text { Average } & 2.65 \\ & \text { (Good) }\end{array}$

Based on the results of tests conducted on media experts obtained an average score of 2.65. These results state that-based learning products online in terms of media which include access, display / interface, learning components and the appropriateness / suitability of the choice of learning components for models online are good. Media experts provide several suggestions for improvement of-based learning products online, namely:

$\underline{\text { Table } 3 \text { Suggestion of Media Experts }}$

\begin{tabular}{|c|c|c|}
\hline No & $\begin{array}{c}\text { Advice from Expert } \\
\text { Experts }\end{array}$ & Research \\
\hline 1. & $\begin{array}{l}\text { What needs to be } \\
\text { considered in } \\
\text { Edmodo's media is } \\
\text { how to upload } \\
\text { programs. }\end{array}$ & $\begin{array}{l}\text { Each material in the } \\
\text { form of a } \\
\text { PowerPoint, pdf, } \\
\text { PowToon and video } \\
\text { file that will be } \\
\text { uploaded to Edmodo } \\
\text { does not experience } \\
\text { problems / problems }\end{array}$ \\
\hline
\end{tabular}

In designing the product, researchers have made content interesting so that users are more

2. $\quad$ content that uploaded to Edmodo interested in reading material on the Edmodo platform.

\section{Material Expert}

Following is the translation of the results of the trial recapitulation of the development of-based learning online in research methodology subjects assessed by material experts

Table 4 Recapitulation of Expert Materials

\begin{tabular}{|c|c|}
\hline Component & Average Assessment \\
\hline Material Quality & 2.40 \\
\hline $\begin{array}{l}\text { 1. Material relevance with } \\
\text { learning / competency } \\
\text { objectives }\end{array}$ & 3 \\
\hline $\begin{array}{l}\text { 2. Adequacy of material } \\
\text { scope to achieve competency }\end{array}$ & 3 \\
\hline 3. Depth of material & 2 \\
\hline $\begin{array}{l}\text { 4. Material accuracy or } \\
\text { validation }\end{array}$ & 2 \\
\hline $\begin{array}{l}\text { 5. Level of difficulty in } \\
\text { studying the material }\end{array}$ & 2 \\
\hline $\begin{array}{l}\text { The accuracy / suitability of } \\
\text { the choice of learning } \\
\text { components for the model } \\
\text { blended learning }\end{array}$ & 2.50 \\
\hline 1. Competence & 3 \\
\hline 2. Material & 2 \\
\hline 3. Method & 3 \\
\hline 4. Evaluation & 2 \\
\hline Average & $\begin{array}{c}2.45 \\
\text { (Fairly Good) }\end{array}$ \\
\hline
\end{tabular}

Based on the results of tests conducted on material experts obtained an average score of 2.45. These results state that-based learning products online in terms of material that includes material quality and the appropriateness / suitability of the choice of learning components for the model online learning are quite good.

Material experts provide some suggestions for improvement of based learning products, online learning namely: 
Table 5 Expert Advice on Materials

\begin{tabular}{ccc}
\hline No & Expert Advice for & $\begin{array}{c}\text { Research } \\
\text { Improvement }\end{array}$ \\
\hline 1. & $\begin{array}{c}\text { Language used is } \\
\text { more slang for } \\
\text { students }\end{array}$ & $\begin{array}{c}\text { Language used in } \\
\text { designing learning } \\
\text { products is formal } \\
\text { language }\end{array}$ \\
Evaluation used is & $\begin{array}{c}\text { evaluation used has } \\
\text { adjusted to } \\
\text { bompetency improved to fit } \\
\text { objectives The }\end{array}$ & $\begin{array}{c}\text { the competency } \\
\text { objectives }\end{array}$ \\
\end{tabular}

\section{Learning Design Experts}

Following the elaboration of the results of the recapitulation of trial products for the development of-based online learning learning in the eyes of the research methodology assessed by learning design experts.

Table 6 Recapitulation of Learning Design Expert

\begin{tabular}{ccc}
\hline & Components & Average Assessment of \\
\hline & Learning Components & 3.5 \\
1. & Completeness of component & 3 \\
2. & Inter-component linkages & 4 \\
& Learning objectives & (competencies)
\end{tabular}

1. Complete details of indicators for each competency

2. Competencies include cognitive, affective and psychomotor aspects

3. Clarity of competency objectives formulation Learning Materials

1. Material relevance with indicators Learning Strategy

1. The accuracy of the selection of learning strategies

2. Carry out apperception

3. Provide stages of learning to achieve competence (scaffolding)

4. Provide opportunities for students to get concrete, meaningful and contextual experiences

5. Encourage students to move, discuss and reflect

6. Stimulating the emergence of awareness of relevance and the need to learn

7. Facing students to a problem that is still within the reach of students (zone of proximal development / ZPD)

8. Give an opportunity to explore
9. Give an opportunity to discuss and get an explanation of the concept

10. Conformity of the

characteristics of learning objectives / competencies with the characteristics of online learning

11. Election statutes learning objectives / competencies to be achieved through online learning

12. The accuracy of choosing the type of material presented through online learning

13. The accuracy of the selection of methods used in online learning 14. The accuracy of the selection of evaluation forms used in online learning

Learning Evaluation

1. Suitability of type and form of evaluation with competency

2. Using a variety of measuring instruments, including memory ability tests and transfer

$$
\text { averages }
$$

Based on the results of tests conducted on learning design experts obtained an average score of 3.23. These results state that the product of the development of based online learning in research methodology courses in terms of learning design which includes the components of learning, learning objectives (competencies), learning materials, learning strategies and evaluation of learning is good. Learning design experts provide some suggestions for product improvements, namely:

Table 7 Learning Design Expert Advice

\begin{tabular}{|c|c|c|}
\hline No & Expert Advice & $\begin{array}{c}\text { Research } \\
\text { Improvement }\end{array}$ \\
\hline 1. & $\begin{array}{c}\text { Need to be consistent } \\
\text { between objectives, } \\
\text { material, selected } \\
\text { learning methods } \\
\text { including the form } \\
\text { of success tests used } \\
\text { The }\end{array}$ & $\begin{array}{l}\text { researcher has } \\
\text { improved the form of } \\
\text { success tests that are } \\
\text { used to be consistent } \\
\text { with the objectives, } \\
\text { material and learning } \\
\text { methods chosen }\end{array}$ \\
\hline
\end{tabular}

\section{9) Revise Instruction (Conducting Revisions)}

After getting an assessment, input and suggestions from experts, the researcher revises-based learning products online learning before continuing to one to one to students. In the second revision the product did not undergo much improvement. 
10) Design and Conduct Summative Evaluation (Design and Conduct Summative Evaluation of User Feasibility Tests

\section{One to one}

At this stage, researchers selected three students as respondents to test based learning products online learning. Three selected students were representatives who received high, medium and low values in the course of the research methodology. besides the three students, they were asked to fill out a questionnaire. Of the three respondents obtained the average value data as follows:

Table 8 average test grades one to one

\begin{tabular}{|c|c|c|c|}
\hline \multirow{2}{*}{ Component of } & \multicolumn{3}{|c|}{ Average Value } \\
\hline & High & Medium & Low \\
\hline Material & 3.0 & 2.67 & 3.33 \\
\hline $\begin{array}{l}\text { 1. The material } \\
\text { presented is clear }\end{array}$ & 3 & 3 & 4 \\
\hline $\begin{array}{ll}2 . & \begin{array}{l}\text { Easy material to } \\
\text { understand }\end{array} \\
\end{array}$ & 3 & 2 & 3 \\
\hline $\begin{array}{l}\text { 3. Pictures and } \\
\text { examples according } \\
\text { to the material } \\
\text { explanation }\end{array}$ & 3 & 3 & 3 \\
\hline Verbal & 2.0 & 3.0 & 3.0 \\
\hline $\begin{array}{l}\text { 1. The use of } \\
\text { media languagesis } \\
\text { easy to understand }\end{array}$ & 2 & 3 & 3 \\
\hline $\begin{array}{l}\text { 2. Explanation of } \\
\text { terms easily } \\
\text { understood media }\end{array}$ & 2 & 3 & 3 \\
\hline Visual & 3.0 & 3.0 & 3.5 \\
\hline $\begin{array}{l}\text { 1. Pictures and } \\
\text { examples on media } \\
\text { clearly }\end{array}$ & 4 & 4 & 3 \\
\hline 2. Media appeal & 3 & 3 & 3 \\
\hline $\begin{array}{l}\text { 3. Matching font } \\
\text { size on media }\end{array}$ & 2 & 2 & 4 \\
\hline $\begin{array}{l}\text { 4. Efficient and } \\
\text { attractive on media } \\
\text { content display }\end{array}$ & 3 & 3 & 4 \\
\hline Video-audio & 3.4 & 3.8 & 6 \\
\hline $\begin{array}{l}\text { 1. The appeal of } \\
\text { the whole learning } \\
\text { video }\end{array}$ & 3 & 3 & 3 \\
\hline $\begin{array}{l}\text { 2. Use of learning } \\
\text { video languages }\end{array}$ & 3 & 3 & 3 \\
\hline
\end{tabular}

Average Value

\begin{tabular}{llll} 
Component of & & & \\
\cline { 2 - 3 } & High & Medium & Low
\end{tabular}

3. The material

presented in the

learning video is in $4 \quad 4 \quad 3$

accordance with the

learning material.

$\begin{array}{llll}\text { 4. Material clarity } & 2 & 3 & 3 \\ \text { and examples given } & & \end{array}$

\begin{tabular}{cccc}
\hline $\begin{array}{c}\text { 5. Increase } \\
\text { learning motivation }\end{array}$ & 2 & 3 & 3 \\
\hline Evaluation & 3.0 & 3.0 & 3.0 \\
\hline $\begin{array}{c}\text { 1. Questions on } \\
\text { the test according to } \\
\text { the material being } \\
\text { discussed }\end{array}$ & 3 & 3 & 3 \\
\hline Average & $\begin{array}{c}2.88 \\
(\text { Good })\end{array}$ & $\begin{array}{c}3.09 \\
(\text { Good })\end{array}$ & $\begin{array}{c}3.29 \\
(\mathrm{Good})\end{array}$ \\
Overall Average & & 3.09 (Good) & \\
\hline
\end{tabular}

Based on the results of trials conducted on three students, the overall average score was 3.09. This result states that in terms of material, verbal, visual, video-audio and evaluation are good. The third gives some suggestions for improvement, namely:

Table 9 Suggestions for Trials one to one

Testimony Suggestions One to One

\begin{tabular}{|c|c|c|c|}
\hline Student 1 & Student 2 & Student 3 & Improvement \\
\hline & $\begin{array}{l}\text { 1. A little } \\
\text { difficult to } \\
\text { understand, }\end{array}$ & & \\
\hline
\end{tabular}

but very

are sometimes important to

too long, and learn and also

like to repeat repeated or

2. There are clarified so some words that it helps to

that are easily

difficult to understand it understand in

English because they are too long

3. Reduce the words in the explanation to make it understandabl e 2.The

language is a little difficult to understand

. It is better to display an explanation with various

1. The material presented is clear, but many words that are difficult to understand because many use English 2. Reducing the use of

English in the explanation of material examples. So that it helps to complete and be easy to understand
1. Repeated words have been fixed 2.Explanation of material that uses English will not be changed with the aim that students want to learn to be able to translate

English text

3. Explanation of etymology material will be

accompanied by an example to be easily understood 


\section{Small Group Assessment}

After getting input and revisions from the one to one trial, the following trials were conducted in a small group of 10 people. Small group assessment is done by testing using the Edmodo platform that has been revised from assessment one to one, then respondents fill out the questionnaire that has been provided. Indicators that are assessed in small groups are the same as those used in one to one.

$\underline{\text { Table } 10 \text { Average Value of Small Group Tests }}$

Component Average Value of

Material 2.73

1. The material presented is clear

2. Material is easy to understand

3. Pictures and examples according to the material explanation

Verbal

1. The use of easy-to-understand media languages

2. Explanation of terms in easily understood media

Visual

1. Pictures and examples on clear media

2. Media attraction

3. Letter size conformity on media

4. Efficient and attractive onmedia content display

Video-audio

1. The appeal of learning videos

2. The use of learning video

$$
\text { language }
$$

3. The material presented in the learning video is in accordance with the learning material

4. Material clarity and examples given

5. Increase learning motivation

$$
\text { Evaluation }
$$

1. Questions on the test according to the material being discussed

$$
\text { Average }
$$

Based on the results of tests conducted on 10 students, the overall average score was 3.01. This result states that the Edmodo platform in terms of material, verbal, visual, video-audio and evaluation is good.

After receiving the assessment, input and suggestions from small group students, the researchers revised the learning material and videos on the Edmodo platform before proceeding to large group research. Learning material and videos on the Edmodo platform did not experience significant improvements. Researchers only change the design to make it look more attractive.

\section{Large Group Research Large}

Group research on students is to determine the quality of development of based online learning learning in the course of research methodology. This stage is carried out on 20 students. Large group research is carried out by applying-based online learning learning in research methodology courses and students fill out the questionnaire provided. The questionnaire used is the same as that used during research one to one and small groups. From 24 respondents, the average value data was obtained as follows.

$\underline{\text { Table } 11 \text { Average Value of Large Group Tests }}$

\section{Component}

Material

1. The material presented is clearly

2. Material is easy to understand

3. Pictures and examples according to the material explanation

$$
\text { Verbal }
$$

1. The use of media languages is easy to understand

2. Explanation of terms in easily understood media

$$
\text { Visual }
$$

1. Images and examples on media are clearly

2. Media attraction

3. Matching font size on media

4. Efficient and attractive on media content display

$$
\text { Video-audio }
$$

1. The appeal of the learning video

2. The use of learning video language

3. The material presented in the learning video is in accordance with learning material 


\section{Clarity of material and examples given}

5. Increase learning motivation

$$
\text { Evaluation }
$$

4. Questions on the test according to the material being discussed

Average

Based on the results of trials conducted on twenty students, the overall average score was 3.40. This result states that the development of based online learning in research methodology subjects in terms of material, verbal, visual, video-audio and evaluation is good.

\section{B. Discussion}

The purpose of this research and development is to produce an based learning model online learning by utilizing the platform Edmodo on the subject of learning methods. The research and development process carried out has produced what is called an based learning model online learning that is applied to research methodology courses in the form of files, pdf, PowerPoint, PowToon and videos that will be uploaded on the Edmodo platform.

Online learning is one revolution in the field of internet technology-based education that can be used for distance education and supporting learning. In its implementation, although both utilizing internet technology online learning does not require learning by using methods online only, but the implementation of learning must still be combined with face-to-face methods. So that the learning process will remain supervised and controlled, for example students who have difficulty understanding when online at night the next day can immediately ask the lecturer about the difficulties, student learning motivation will be maintained. So that the role of the teacher as a supervisor and manager of education is still maintained.

In implementing online learning there are main factors, namely: (1) facilities and infrastructure, (2) lecturers need to improve their abilities in the field of ICT by reading and practicing independently or through formal training, and (3) students need to gain access to computers and the internet and have the ability to use E-Learning. In order for optimal learning, these three factors must be fulfilled and carried out properly, the study program and faculty must strive to support and fulfill the facilities and infrastructure to support lecturers in developing their abilities in the ICT field and strive for students to gain access to computers and the internet. If the effort is implemented, the implementation of online learning will run optimally.

The implementation of online learning is seen still having difficulties in distinguishing the implementation of e-learning and online learning. In applying online learning with strategy full online (full line), would be tantamount to an e-learning where the lecturer is less prominent role, that the difference between e-learning and online learning is the right composition in managing strategy, online, offline and face to face, the composition distribution is absolutely carried out by the lecturers so that the learning objectives can be achieved. So, it needs to be studied how the process of implementing online learning and how to optimize online learning so that it can run effectively and efficiently.

Planning for based online learning on research methodology courses using the Edmodo platform has the strengths and weaknesses of the program which will be described as follows.

\section{1) Strength of the Program}

Considering that this program was developed based on the internet and uses the Edmodo platform that has been tested for reliability, this platform has several advantages, including:

- Lecturers and students can carry out online based learning processes learning using the Edmodo platform by utilizing some features available in Edmodo to upload and download material to be learned in face-to-face learning and learning online.

- Students can take advantage of the feature chat on the Edmodo platform to be able to communicate with lecturers.

- Edmodo Platform provides an environment where teaching and learning can generate student excitement, students become more independent, without forgetting student measurement success standards.

- In essence the Edmodo platform is easy to learn and easy to use especially for lecturers who consider themselves to be outside the current technological knowledge base that is developing.

- Evaluations carried out especially evaluations that use objective tests, enable processing of scores automatically.

2) Weaknesses of the Program

In addition to the strengths above, this program online learning is not immune from weaknesses. The weaknesses that appear during the evaluation process are:

- This program requires a stable network and internet connection, especially when doing the learning process online and doing tests. If the network and connection are not stable, when we do discussions online, we are often left behind / slow in posting opinions, so that what is delivered is not "connected". Even worse if the instability occurs while working on the test, it is possible that when the test has not been completed the network and its connection are interrupted, so not all questions are resolved. This condition is certainly problematic for students.

- Evaluation system in essay form is not flexible in examination. With an evaluation system in the form of an essay test online, student answers will be sent and recorded in a database (server), but because essay questions cannot be checked automatically, the examination must still be manual, they must be opened and read their answers individually This is where the irregularity is. In the examination the teacher relies heavily on internet access. At the time of inspection, the program must always open and score each answer to be saved in a

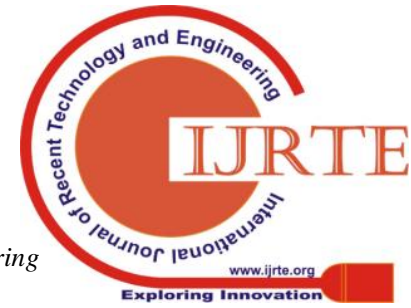




\section{Network Based Online Learning Program Vocational School in Jakarta State University}

database (server) so that the results can be seen by students.

- With an evaluation system that is carried out online, it allows them to work on tests by collaborating, especially if the tests are carried out during the lecture hours. Other weaknesses allow them to open books to answer questions (questions).

\section{Conclusion}

Based on the explanation on the objectives and results obtained in the research development of based online learning in the course of research methodology, conclusions can be drawn:

- $\quad$ The initial research was carried out in the electrical engineering vocational education study program involving 23 students. The initial research was conducted to obtain information on the needs of students to design based learning models online learning. This information is used as a guideline for developing based learning models online learning.

- $\quad$ The development of based online learning learning in the research methodology course uses Dick and Carey's learning development model using the Edmodo platform.

- The development of based online learning which consists of .pdf, ppt, word, PowToon and video files can be very well received by students.

- Student interest and interest have increased but student learning outcomes have not been maximized. This is because the based learning model is online learning still relatively new, so it requires a short time process.

\section{ACKNOWLEDGEMENTS}

This research work is supported by Jakarta State University.

\section{REFERENCES}

[1] Prawiradilaga DS. Mozaik Teknologi Pendidikan E-Learning. Jakarta: Kencana Prenadamedia Group; 2013.

[2] Trianto. Model Pembelajaran Terpadu: Konsep, Strategi, dan Implementasinya dalam Kurikulum Tingkat Satuan Pendidikan (KTSP). Jakarta: Bumi Aksara; 2015. 51 p.

[3] Prawiladilaga DS. Wawasan Teknologi Pendidikan Jakarta. Jakarta: Kencana Prenada Media Group; 2012.

[4] Dabbagh N dan BBR. Online Learning: Concepts, Strategies and Application. New Jersey: Pearson Prentice Hall; 2005. 15 p.

[5] Sharon E. Smaldino DLLJDS. Instructional Technology \& Media For Learning Teknologi Pembelajaran dan Media untuk Belajar. Penterjemah : Arif Rahman. Kencana, editor. Jakarta; 2012. 302 p.

[6] Rita C. Richey, James D. Klein and MWT. The Instructional Design Knowledge Base Teori, Researh, and Practice. New York: Routledge; 2011. 3 p.

[7] Alan, Jolliffe., Jonathan, Ritter dan DS. The Online Learning Handbook- Developing and Using Web-Based Learning. UK: Kogan Page Limited; 2001. 61 p.

[8] Linda H. Learning Theory and Online Technologies. New York: Routledge; 2012.87 p.

[9] Haughey, M. \& Anderson T. Networked Learning: The pedagogy of the Internet. Montreal: Cheneliere/McGraw-Hill; 1998.

[10] Roblyer M. Integrating Educational Technology into Teaching. New Jersey: pearson; 2016. 234-235 p.

[11] Walter Dick LC dan JOC. The Systematic Design of Instruction 7ed. Boston: pearson; 2009. 6-7 p.

\section{AUTHORS PROFILE}

I am Suyitno Muslim, working as Profesor at Universitas Negeri Jakarta, Rawamangun Muka Street, Rawamangun, Pulogadung, East Jakarta, 13220, Indonesia.my area of interest in E learning and technology management.

My name is Jhoni Lagun Siang, I am associated with Post Graduated Department of Educational Technology Universitas Negeri Jakarta, Rawamangun Muka Street, Rawamangun, Pulogadung, East Jakarta, 13220, Indonesia. my area of interest in E learning and technology management.

I am Aniesa Puspa Arum, I am associated with Post Graduated Department of Educational Technology Universitas Negeri Jakarta, Rawamangun Muka Street, Rawamangun, Pulogadung, East Jakarta, 13220, Indonesia. my area of interest in E learning and technology management. 